\title{
EXPRESSION, PURIFICATION AND CHARACTERIZATION OF CHITINASE CHIC PRECURSOR FROM Streptomyces peucetius
}

\author{
Amrathlal Rabbind Singh ${ }^{\mathrm{a},{ }^{*}}$, Chitra Thangavel ${ }^{\mathrm{b}}$, Kuppamuthu Dharmalingam $^{\mathrm{c}}$ \\ Department of Genetic Engineering, School of Biotechnology, Madurai Kamaraj University, Madurai, 625021, India \\ Received - May 27, 2018; Revision - July 25, 2018; Accepted - August 02, 2018 \\ Available Online - August 10, 2018 \\ DOI: http://dx.doi.org/10.18006/2018.6(4).669.676
}

\section{KEYWORDS}

E. coli M15pREP4

Chitinase precursor

Fibronectin type III

Secreted chitinase

Proteolytic cleavage

Glycosylation

\begin{abstract}
Chitinase (ChiC) of Streptomyces peucetius produced as a precursor protein undergoes proteolytic cleavage to yield a $42 \mathrm{kDa}$ protein. Specific activity and cellular location of the proteolytic cleavage is however unknown. In order to decipher the functional characteristics of the precursor, we amplified the coding region of chiC using polymerase chain reaction and cloned the chiC gene with its signal peptide in an E. coli expression vector pQE-30. Upon induction with IPTG, a protein of $66 \mathrm{kDa}$ could be seen and this matched the theoretical molecular weight of full length ChiC chitinase precursor. The expressed protein was found localized in inclusion bodies, thus purification was performed under denaturing conditions using Ni-affinity chromatography. $66 \mathrm{kDa}$ ChiC precursor protein purified under denaturing conditions was refolded to yield an active enzyme. Enzymatic activities of the precursor and secreted form were compared. Western analysis of the S. peucetius intracellular and secreted proteins identified the location of proteolytic cleavage.
\end{abstract}

Present addresses:

${ }^{a}$ Centre for Genomics, Jiwaji University, Gwalior, 474001, INDIA

${ }^{\mathrm{b}}$ Proteomics Laboratory, Ganga Research Centre, Ganga Orthopedic Research \& Education Foundation (GOREF), Kavundampalayam, Coimbatore, 641012, INDIA ${ }^{\mathrm{c}}$ Aravind Medical Research Foundation, No.1, Anna Nagar, Madurai. 625020, INDIA

* Corresponding author

E-mail: rabbind@gmail.com (Amrathlal Rabbind Singh)

Peer review under responsibility of Journal of Experimental Biology and Agricultural Sciences.

Production and Hosting by Horizon Publisher India [HPI] (http://www.horizonpublisherindia.in/).

All rights reserved.
All the article published by Journal of Experimental Biology and Agricultural Sciences is licensed under a Creative Commons Attribution-NonCommercial 4.0 International License Based on a work at www.jebas.org.

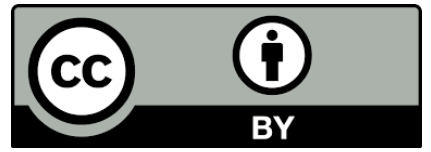




\section{Introduction}

Streptomyces are gram positive, soil bacteria belonging to order actinomycetales characterized by a high genomic GC content (Hutchings et al., 2004; Rodríguez et al., 2013). These microorganisms produced wide variety of enzymes such as chitinases, xylanases, cellulases, proteases and amylases (Gilbert et al., 1995; Vetrivel et al., 2001). Apart from commercially important enzymes these microbes also produce a plethora of secondary metabolites and these compounds are routinely used as antibiotics, chemotherapeutic agents, immune suppressants etc. (Sheeler et al., 2005; Zothanpuia et al., 2017). Streptomyces peucetius a producer of anticancer antibiotics doxorubicin and daunorubicin used in cancer chemotherapy also produces an extracellular chitinase (ChiC) (Vetrivel \& Dharmalingam, 2001; Vetrivel et al., 2001). Chitinases are produced by various groups of organisms ranging from bacteria (Vetrivel et al., 2001) to humans (Renkema et al., 1997). These enzymes hydrolyze chitin which is a $\beta-1,4$ linked homopolymer of N-acetyl-D-glucosamine. Streptomyces are the main decomposers of chitin in nature (Okazakiet al., 2004) since they can utilize chitin as a source of carbon and nitrogen thereby playing a significant role in the turnover of chitin (Saito et al., 2001), second most abundant polysaccharide in nature.

Chitinolysis in bacteria is performed by three separate enzymes namely endochitinases which produce multimers of $\mathrm{N}$ acetlyglucosamine (NAG), exochitinases which produce low molecular weight dimers of chitibiose, which are later hydrolyzed to NAG by chitobiases (Gomes et al., 2001). Whole genome sequencing reported the presence of multiple genes for chitinases in the chromosome of $S$. coeliocolor (Bentley et al., 2002), $S$. avermitillis (Omura et al., 2001) as well as S. griseus (Ohnishi et al., 2008). It was also observed that higher number of chitinase genes were present in Streptomyces (Omura et al., 2001;Bentley et al., 2002; Ohnishi et al., 2008) in comparison to other chitin degrading bacteria such as Bacillus circulans (Watanabe et al., 1990) and Serratia marcescens (Suzuki et al., 2002). Simultaneous induction of five chitinase genes of $S$. coelicolor (chiA, B, C, D, F) in the presence of colloidal chitin proved that chitin degradation is the result of synergistic action of many chitinases (Saito et al., 2000).

Streptomyces chitinases are modular enzymes with their modules organized in the following order from $\mathrm{N}$-terminus i.e. signal peptide, substrate-binding domain, fibronectin-type III like domain (also termed as accessory domain) and a catalytic domain. Chitinases are not the only enzymes having accessory domains in addition to catalytic domains, enzymes such as amylases, cellulases, xylanases and pectinases also possess (Saito et al., 2003).
Previous studies have also shown that $S$. peucetius secretes a chitinase (ChiC) of $42 \mathrm{kDa}$. This protein was purified to homogeneity from culture supernatant (Vetrivel et al., 2001) and its gene cloned from the genomic library constructed in $\lambda$ Dash II and sequenced. Sequence analysis showed that $c h i C$ gene could encode a $65.4 \mathrm{kDa}$ protein containing a signal peptide, type III fibronectin like domain, substrate binding domain and catalytic domain (ChiC precursor protein). In addition to the expression and purification of the protein from E. coli we also compared the specific activities of secreted $\mathrm{ChiC}$ and ChiC precursor. This study was designed to decipher the functional characteristics of ChiC precursor.

\section{Materials and Methods}

\subsection{Reagents and Chemicals}

Ni-Sepharose used for purification was purchased from GE healthcare (Pittsburgh, USA), Goat anti Rabbit IgG (Horse Radish Peroxidase) from Bangalore genei (Bangalore, INDIA). All other chemicals were either purchased from Sigma (St. Louis, USA) or Merck (Mumbai, INDIA). Primers were synthesized and obtained from Sigma Aldrich Chemicals Pvt Ltd (Bangalore, INDIA). Restriction enzymes, $P f u$ polymerase and T4 DNA ligase were purchased either from GE health care (Pittsburgh, USA) or MBI Fermentas (Mumbai, INDIA). Bacterial culture media components were purchased from HiMedia Laboratories (Mumbai, INDIA).

\subsection{Bacterial strains and Plasmids}

Expression vector pQE-30 and E. coli strain M15pREP4 used as an expression host were procured from Qiagen, Inc. (USA) and $E$. coli strain XL1 blue MRF' was used as a cloning host. pGEM-T vector (Promega, Madison, USA) was used for cloning the PCR amplicon.

\subsection{Construction of ChiC expression plasmid}

Full length chiC gene was amplified by PCR using primers ChiCPF (5' AGg gat ccA TGT CCG CAC TCA ACT CG3') and ChiCPR (5'ACC aagettCAA TGT GGC GTG AAG GGG 3'). BamHI and HindIII sites incorporated in the primers are shown in lower case. Plasmid pSPVC2.3, a derivative of pSET152 carrying a $5 \mathrm{~kb}$ genomic library fragment harboring chiSRC locus was used as template in PCR. The obtained amplicon was cloned using pGEM-T vector and the resulting recombinant plasmid was designated as pChiC. DNA fragment containing the chic coding region was released by restriction digestion using BamHI and HindIII from pChiC and ligated to pQE-30 digested with BamHI and HindIII to obtain pQEChiC. In-frame fusion of 6xHis tag and chic ORF was confirmed by DNA sequencing. 


\subsection{Expression and localization of $\mathrm{ChiC}$}

E. coli strain M15pREP4 was transformed with pQEChiC. To check for the expression of $\mathrm{ChiC}$, cultures were grown in $\mathrm{LB}$ medium at $37^{\circ} \mathrm{C}$ to an optical density of $0.6 \mathrm{OD}(600 \mathrm{~nm})$ and IPTG was added to a final concentration of $1 \mathrm{mM}$ to induce the expression of $c h i C$, culture was allowed to grow further and samples were taken after two and four hours. Cell pellet was suspended in SDS lysis buffer (25 mMTris pH 8.0 and $0.3 \%$ SDS) and incubated in a boiling water bath for $5 \mathrm{~min}$. The lysate was clarified by centrifugation at $12,000 \mathrm{rpm}$ for $5 \mathrm{~min}$ and the clear supernatant was analyzed on $12 \%$ polyacrylamide gel (Laemmli, 1970).

In order to localize the expressed $\mathrm{ChiC}$ precursor $20 \mathrm{ml}$ induced cell pellet was suspended in one milliliter of sonication buffer (50 mMTris $\mathrm{pH} 7.8,300 \mathrm{mMNaCl}$ ) and sonicated for $3 \mathrm{~min}$ on ice. Cell debris was eliminated by centrifugation at 3,000 rpm for two minutes. Supernatant was collected and centrifuged at 12,000 rpm for $5 \mathrm{~min}$ to pellet the inclusion bodies. Supernatant which has the soluble proteins was stored and pellet was washed once with sonication buffer. Pellet containing the inclusion bodies was resuspended in $250 \mu \mathrm{l}$ sonication buffer containing $2 \mathrm{M}$ urea followed by vortexing for $15 \mathrm{~min}$ following which the mixture was centrifuged at 4,000 rpm for $10 \mathrm{~min}$ and $2 \mathrm{M}$ supernatant was collected. The pellet was suspended in $4 \mathrm{M}, 6 \mathrm{M}$, and $8 \mathrm{M}$ urea and processed in a similar manner. Protein content was estimated by Bradford's dye binding method and equal concentration of protein was loaded onto $12 \%$ polyacrylamide gel. Proteins were visualized by staining the gel with colloidal coomassie stain.

\subsection{Purification and refolding of ChiC precursor}

Purification was performed under denaturing conditions as per Qiagen manual with certain modifications suggested by Rabbind Singh et al.(2014). Cell pellet from $500 \mathrm{ml}$ induced culture was suspended in $20 \mathrm{ml}$ buffer $\mathrm{A}$ and incubated at $30^{\circ} \mathrm{C}$ for $30 \mathrm{~min}$, cell debris was removed by centrifuging the lysate at $12,000 \mathrm{rpm}$ for $30 \mathrm{~min}$ at $4^{\circ} \mathrm{C}$ and clear supernatant was loaded onto $2 \mathrm{ml} \mathrm{Ni}$ Sepharose column pre-equilibrated with buffer $\mathrm{A}$ and flow rate was maintained at $15 \mathrm{ml}$ per hour. Non-specifically bound proteins were removed by washing the column with 10 column volumes of buffer A and followed by 10 column volumes of buffer B, buffer $\mathrm{C}$ and buffer $\mathrm{D}$. Bound protein was eluted in 5 column volumes of buffer $\mathrm{E}$ and buffer $\mathrm{F}$. Two $\mathrm{ml}$ fractions were collected and the presence of protein was checked on $12 \%$ polyacrylamide gel. The fractions containing the pure protein were pooled and dialyzed in refolding buffer (50 mMTris $\mathrm{pH} 8.0$, $100 \mathrm{mMNaCl}, 10 \%$ Glycerol and $500 \mathrm{mM} \mathrm{L}$ - Arginine) (Tsumoto et al., 2004) for 16 hours at $4^{\circ} \mathrm{C}$.
2.6 In gel trypsin digestion and MALDI TOF mass spectrometry

SDS-PAGE was performed with $12 \%$ polyacrylamide gel and proteins visualized by staining with colloidal Coomassie stain. Protein bands were excised with a sterile blade, gel pieces minced and destained. Tryptic digestion and MALDI-TOF was performed as described by Lini et al. (2008). Peptide mass fingerprint (PMF) was acquired using Axima CFR plus 210 (KRATOS Shimadzu) MALDI-TOF mass spectrometer. The mono isotopic masses were used for identification in MASCOT search engine, version 2.1 (www.matrixscience.com). Search was performed in NCBInr with the parameters as follows: Tolerance $- \pm 0.2 \mathrm{Da}$, maximum number of missed cleavages- 0 .

\subsection{Chitinase assay}

Induced and uninduced cell pellets were suspended in sonication buffer and the cells were disrupted by sonication at $35 \%$ amplitude for 10 cycles ( 5 secs on, 5 secs off). The lysate was clarified by centrifugation at $12,000 \mathrm{rpm}$ for $5 \mathrm{~min}$ and the clear supernatant was used to measure the chitinase activity. The assay for chitinase was carried out as described previously (Paranthaman \& Dharmalingam, 2003) using the fluorogenic substrate 4-methylumbelliferyl- $N, N^{\prime}, N^{\prime \prime}$-triacetylchitotriose (Sigma Chemical Co, St. Louis, USA). The amount of 4methylumbelliferone liberated was measured using a fluorimeter (Hoefer, Holliston, USA) with an excitation wavelength of 365 $\mathrm{nm}$ and an emission wavelength of $460 \mathrm{~nm}$. One unit of chitinase activity is defined as the amount of enzyme required to liberate 1 $\mu \mathrm{mol}$ of 4-methylumbelliferone from the substrate in $1 \mathrm{~min}$ at $37^{\circ} \mathrm{C}$.

\subsection{Preparation of total extracellular proteins of S. peucetius}

S. peucetius was grown in Nitrate Defined Medium with $0.5 \%$ chitin (NDMC) (2) for 120 hours at $30^{\circ} \mathrm{C}$ (Paranthaman \& Dharmalingam, 2003). The culture filtrate obtained was concentrated by precipitation using equal volume $20 \%$ TCA in acetone for $14 \mathrm{hrs}$ at $4^{\circ} \mathrm{C}$ followed by centrifugation at 12,000 rpm for $15 \mathrm{~min}$ at $4^{\circ} \mathrm{C}$. The pellet was washed twice with chilled acetone, air dried and suspended in $100 \mu \mathrm{l}$ SDS lysis buffer by placing in a boiling water bath for $5 \mathrm{~min}$. Protein content was measured by Bradford's dye binding method and the samples were stored at $-70^{\circ} \mathrm{C}$ till further use.

\subsection{Western blot}

Protein samples were separated on $12 \%$ polyacrylamide gel and electroblotted to nitrocellulose membrane using Hoefertransblot western blotting apparatus. The membrane was blocked with $5 \%$ milk powder in $10 \mathrm{mMTris}-\mathrm{HCl}(\mathrm{pH} 7.5)$ with $150 \mathrm{mMNaCl}$ and $0.1 \%$ Tween 20 (TBST) for $2 \mathrm{hrs}$ at room temperature. The 
membrane was then incubated for 12 hours at $4{ }^{\circ} \mathrm{C}$ with rabbit anti-Secreted ChiC antibody (diluted 1:1000 in TBS with $0.1 \%$ milk powder) (Vetrivel et al., 2001). After three washes with TBST, the membrane was incubated for one hour with Horse radish peroxidase-conjugated secondary antibody (goat anti-rabbit IgG, diluted $1: 1000$ in TBS with $0.1 \%$ milk powder). The membrane was washed three times with TBST and the specific protein bands were visualized by using DAB (3, 3'Diaminobenzidine).

\section{Results}

\subsection{Cloning and Expression of chiC precursor in E. coli}

Nucleotide sequence analysis of the plasmid indicated that an open reading frame of 1890 bases could encode a $65.4 \mathrm{kDa}$ protein, based on sequence homology and $\mathrm{N}$-terminal amino acid sequence it was proposed that $65.4 \mathrm{kDa}$ protein is the precursor of chitinase (Vetrivel et al., 2001). Comparison of amino acid sequences revealed an $\mathrm{N}$-terminal signal peptide, substrate binding domain, fibronectin type III like domain and the catalytic domain (Vetrivel et al., 2001). The domain organization of precursor and secreted $\mathrm{ChiC}$ is shown in figure 1.

In order to analyze the functions of chitinase precursor, chiC gene was cloned in E. coli. The recombinant plasmid pQEChiC was generated, used to transform M15pREP4 and transformants were checked for expression as described in materials and methods. Lysates prepared from cultures showed a protein band of $66 \mathrm{kDa}$ when induced with IPTG. This band was absent in lysates from un-induced cultures (figure 2A). The $66 \mathrm{kDa}$ band was cut from SDS-PAGE and subjected to in gel digestion by trypsin and peptides were analyzed in a MALDI-TOF mass spectrometer. MASCOT search using the MS data identified the protein as Chitinase C precursor from $S$. peucetius with a score of 84 and sequence coverage of $18 \%$, interestingly of the six peptides matching the sequence in the database three peptides matched the $\mathrm{N}$-terminus region, which was cleaved of in the secreted protein (Table 1).

\section{S. peucetius ChiC precursor protein}

\section{S. peucetius ChiC secreted protein}

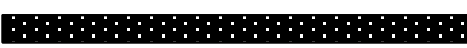

Signal peptide

N substrate binding domain

Figure 1 Modular organization of Chitinase (ChiC) from S. peucetius.
I Type III fibronectin-like domain

Catalytic domain

Table 1 Identification details for ChiC precursor from MASCOT PMF search

\begin{tabular}{|c|c|c|}
\hline Peptides matched & Protien identification & Sequence coverage and \\
& & assession number \\
\hline NTGTTTINSWTVEWDFPSGTK & Chitinase C precursor - Streptomyces peucetius & $18 \%$ \\
VTSAWDATVTNSGDHWTAK & Mass: $65.3 \mathrm{kKa}$ & gi|7248705 \\
VATVTGTTYTNTGLTAGTDYSYTIQAR & Calculated pI palue 6.39 & Score: 84 \\
LGYFTNWGVYGR & & \\
ITHINYAFGNVSGGK & & \\
AYTADQSVDGVADTWDQPLR & & \\
\hline
\end{tabular}

Journal of Experimental Biology and Agricultural Sciences http://www.jebas.org 
A

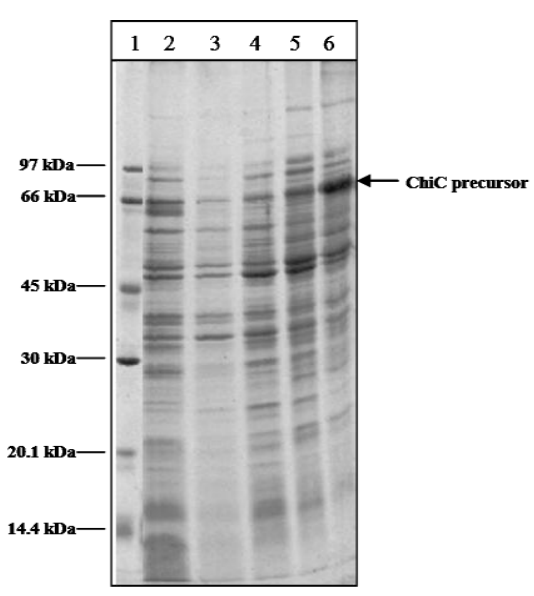

B

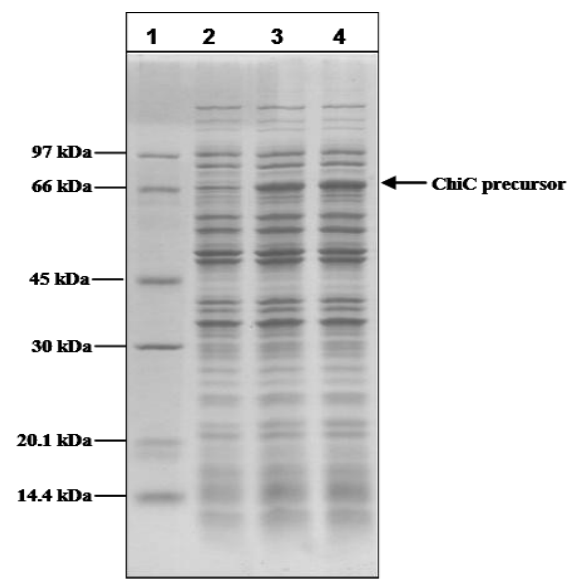

Figure 2 Expression of recombinant ChiC precursor protein in M15pREP4 and localization.(A) Samples were electrophoresed on $12 \%$ Polyacrylamide gel and stained with Coomassie blue as described. The cell lysate was prepared from induced cultures of M15pREP4 pQEChiC. $20 \mu \mathrm{g}$ protein was loaded in each lane. Lane 1, Protein molecular weight marker; Lane 2, before induction; Lane 3, 2 hours after induction; Lane 4, 4 hours after induction.(B) Samples were prepared as described in materials and methods and electrophoresed on a $12 \%$ Polyacrylamide gel and stained with Coomassie blue. Lane 1, Protein molecular weight marker; Lane 2, soluble fraction; Lane 3, 2M Urea supernatant; Lane 4, 4M Urea supernatant; Lane 5,6M Urea supernatant; Lane 6,8M Urea supernatant. $15 \mu \mathrm{g}$ protein loaded in lane 2, 4, 5, 6 and $10 \mu \mathrm{g}$ protein was loaded in lane 2.

\subsection{Purification, Refolding and enzymatic assay of ChiC precursor}

Chitinase activity was measured in the clarified lysates from $E$. coli expressing ChiC as described under materials and methods. The enzymatic activity in the lysate was negligible $(1.3 \mathrm{U} / \mathrm{mg})$. Low level of enzymatic activity could be due to the formation of inclusion bodies containing ChiC protein and the inclusion bodies could have been lost in the pellet during centrifugation step. Lini et al. (2008) showed that inclusion bodies are soluble only in $8 \mathrm{M}$ urea unlike protein aggregates which are soluble in $4 \mathrm{M}$ urea. Data in figure $2 \mathrm{~B}$ shows that ChiC precursor is indeed present in inclusion bodies. Therefore, $\mathrm{ChiC}$ precursor protein was purified to homogeneity under denaturing conditions using Ni-affinity chromatography (figure 3 ).

\subsection{Specific activity of Chitinase precursor and secreted Chitinase}

Chitinase precursor purified from E. coli as described in materials and methods was refolded and assayed for chitinase activity. Secreted chitinase purified from the extracellular medium of $S$. peucetius culture showed three fold higher specific activities in comparison to the precursor. Reduced specific activity of chitinase precursor was consistently observed when protein purified from three independent experiments was used for comparison. When both the proteins were denatured by placing in boiling water bath for $5 \mathrm{~min}$ they lost their activity (figure 4).

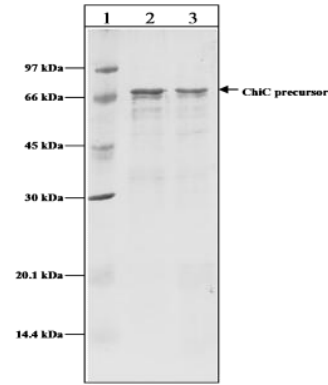

Figure 3 Purification of ChiC precursor using Ni - Affinity Chromatography. Samples were electrophoresed on $12 \%$ Polyacrylamide gel and stained with Coomassie blue as described. The protein was purified as described in materials and methods. Lane 1, Protein molecular weight marker; Lane 2, $3 \mu \mathrm{g}$; Lane $3,1.5 \mu \mathrm{g}$ of purified precursor.

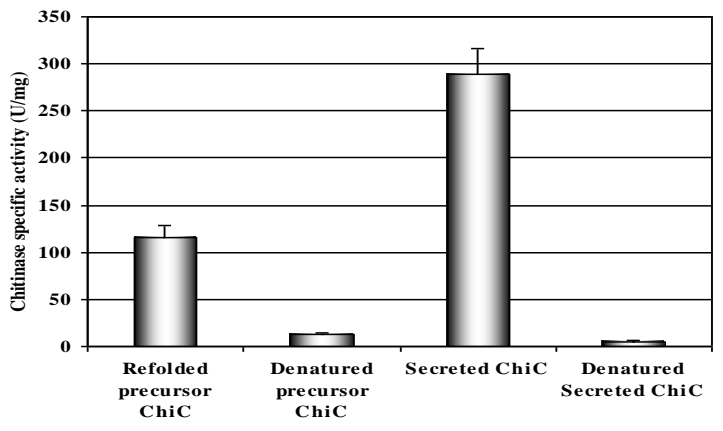

Figure 4 Comparison of chitinase activities of refolded and Secreted ChiC purified from S. peucetius. Chitinase assay was performed as described in materials and methods. 

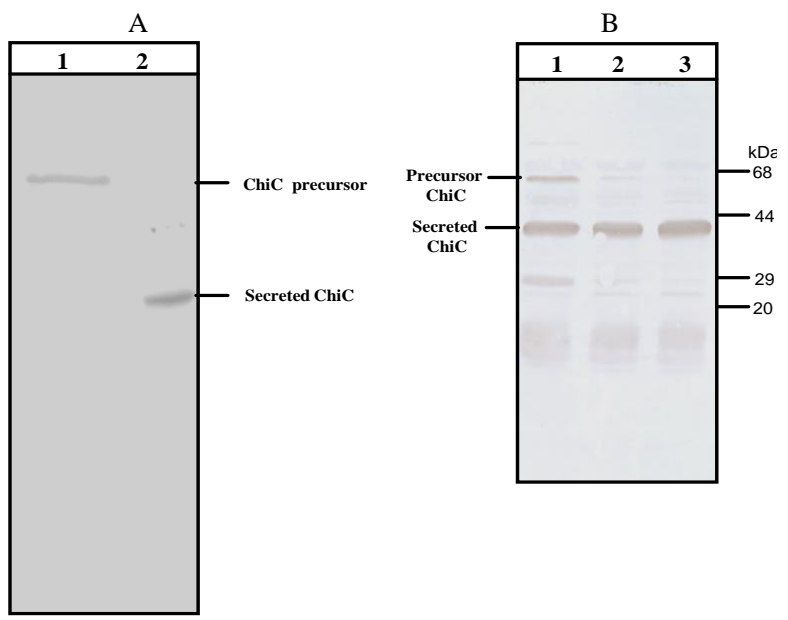

Figure 5 Western blot analysis was performed using anti secreted ChiC antibodies as described in materials and methods. Proteins were electrophoresed on a $12 \%$ Polyacrylamide gel, blotted onto nitrocellulose membrane and detected using anti secreted chitinase anti bodies. (A) Lane 1, $2 \mu \mathrm{g}$ Purified ChiC precursor; Lane 2, $2 \mu \mathrm{g}$ Purified secreted ChiC. (B) Total extracellular proteins were electrophoresed on a $12 \%$ Polyacrylamide gel, blotted onto nitrocellulose membrane and detected using anti secreted ChiC anti bodies. Lane 1, 48 hrs; Lane 2, 72 hrs; Lane 3, 96 hrs.

\subsection{Western blot analysis of the purified protein}

Anti-ChiC antibodies were raised in rabbits as described earlier (Vetrivel et al., 2001) by using secreted chitinase purified from $S$. peucetius culture filtrate as antigen. These antibodies were tested for their cross reactivity with precursor chitinase purified from $E$. coli and found that they cross reacted (figure 5A). Based on these results it can be concluded that the antibodies raised against the secreted chitinase could be used for studying post translational proteolytic cleavage of ChiC precursor in S. peucetius.

\subsection{Expression of ChiC precursor is transient in S. peucetius}

In order to examine the presence of ChiC precursor we analyzed the total extracellular proteins of $S$. peucetius grown in NDMC medium. Protein samples were prepared as mentioned in materials and methods. Western analysis using anti $\mathrm{ChiC}$ antibodies showed that the antibodies cross reacted with three proteins of approximately $66 \mathrm{kDa}, 42 \mathrm{kDa}$ and $29 \mathrm{kDa}$. The $66 \mathrm{kDa}$ band was very intense in culture which was grown for $48 \mathrm{hrs}$. The $42 \mathrm{kDa}$ protein which is the secreted $\mathrm{ChiC}$ was seen in all the three time points at equal concentration, similarly a protein of $29 \mathrm{kDa}$ also showed a similar trend to that of $66 \mathrm{kDaprotein}$ (figure 5B).

\section{Discussion}

High level expression of heterologous proteins in E. coli often leads to the formation of inclusion bodies. However, localization of a protein in inclusion bodies is advantageous when the expressed protein is toxic or lethal to the cell. Nevertheless this advantage may not serve the purpose when there is a need to have the protein in native confirmation. Recent developments in protein refolding lead to the development of many new methods. Each method has its own shortcomings like in the case of dilution based refolding the protein gets diluted and requires concentrating the protein using centrifugal devices (Girish et al., 2006), we have also used matrix assisted refolding (Saini et al., 2002) for refolding $S$. peucetius chitinase histidine kinase (ChiS) and found that dialysis based refolding in the presence of L-Arginine is more efficient in comparison to matrix assisted refolding (these results will be published elsewhere).

In this study we have purified recombinant chitinase precursor of $S$. peucetius using Ni-affinity chromatography and on dialyzing over a period of 16 hours the protein regains activity. ChiC is a modular chitinase having a N-terminal signal peptide, a substrate binding domain, a fibronectin type III domain, and a catalytic domain (figure 1). These domains share very high sequence homology to ChiC of S. coelicolor (Vetrivel et al., 2001). Significance of signal peptide, substrate binding domain and catalytic domain is known for many chitinases. We compared the specific activities of Chitinase precursor having all four domains and secreted chitinase having the catalytic domain alone (Vetrivel et al., 2001) and found that secreted ChiC has nearly three folds higher specific activity than the precursor. It has been also reported that secreted ChiC is glycosylated in S. peucetius and the significance of glycosylation on the activity of enzyme is still not clear and thereby the difference of specific activity between Chitinase precursor and secreted Chitinase can probably be attributed to glycosylation of secreted ChiC, since E. coli lacks glycosylation machinery (Singh et al., 2005). Is the decrease in specific activity of precursor due to the presence of fibronectin type III domain also needs to be investigated comprehensively. Polyclonal antibodies raised against secreted $\mathrm{ChiC}$ were used in western analysis, they picked up the ChiC precursor protein based on which we performed western analysis with $S$. peucetius total extracellular proteins to detect the precursor. We could detect the $66 \mathrm{kDa} \mathrm{ChiC}$ precursor protein indicating that the proteolytic cleavage occurs in the extracellular milleu. Experiments to understand the biochemical nature of protease involved in the cleavage of precursor are underway. The availability of sufficient amounts of functionally active ChiC precursor is an essential step to study the process of proteolytic cleavage and the role of glycosylation in S. peucetius ChiC.

\section{Acknowledgements}

This research was supported by the grant for CGESM (BT/IS/03/002/87-Vol III) and NFCP (BT/INF/22/2/2007) from the Department of Biotechnology, Government of India, New Delhi, India, to K.D. 


\section{Conflict of Interest}

Authors would hereby like to declare that there is no conflict of interests that could possibly arise.

\section{References}

Bentley SD, Chater KF, Cerdeno-Tarraga AM, Challis GL, Thomson NR, James KD, Harris DE, Quail MA, Kieser H, Harper D, Bateman A, Brown S, Chandra G, Chen CW, Collins M, Cronin A, Fraser A, Goble A, Hidalgo J, Hornsby T, Howarth S, Huang CH, Kieser T, Larke L, Murphy L, Oliver K, O'Neil S, Rabbinowitsch E, Rajandream MA, Rutherford K, RutterS, Seeger K, Saunders D, Sharp S, Squares R, Squares S, Taylor K, Warren T, Wietzorrek A, Woodward J, Barrell BG, Parkhill J, Hopwood DA (2002) Complete genome sequence of the model actinomycete Streptomyces coelicolor A3(2). Nature 417:141-147.

Gilbert M, Morosoli R, Shareck F, Kluepfel D (1995) Production and secretion of proteins by streptomycetes. Critical Reviews in Biotechnology 15 :13-39.

Girish KR, Palanivelu S, Kumar PD, Usha R (2006) Refolding, purification and characterization of replication-initiator protein from soybean-infecting geminivirus. Journal of Virological Methods $136: 154-159$.

Gomes RC, Semedo LT, Soares RM, Linhares LF, Ulhoa CJ, Alviano CS, Coelho RR (2001) Purification of a thermostable endochitinase from Streptomyces RC1071 isolated from a cerrado soil and its antagonism against phytopathogenic fungi. Journal of Applied Microbiology 90 :653-661.

Hutchings MI, Hoskisson PA, Chandra G, Buttner MJ (2004) Sensing and responding to diverse extracellular signals? Analysis of the sensor kinases and response regulators of Streptomyces coelicolorA3(2). Microbiology $150: 2795-2806$.

Laemmli UK (1970) Cleavage of structural proteins during the assembly of the head of bacteriophage T4. Nature 227 :680-685.

Lini N, Rehna EA, Shiburaj S, Maheshwari JJ, Shankernarayan NP, Dharmalingam K (2008) Functional characterization of a small heat shock protein from Mycobacterium leprae. BMC Microbiology 8:208.

Ohnishi Y, Ishikawa J, Hara H, Suzuki H, Ikenoya M, Ikeda H, Yamashita A, Hattori M, Horinouchi S (2008) Genome sequence of the streptomycin-producing microorganism Streptomyces griseus IFO 13350. Journal of Bacteriology 190: 4050-4060.

Okazaki K, Yamashita Y, Noda M, Sueyoshi N, Kameshita I, Hayakawa S (2004) Molecular cloning and expression of the gene encoding family 19 chitinase from Streptomyces sp. J-13-3. Bioscience, Biotechnology, and Biochemistry 68 : 341-351.

Omura S, Ikeda $\mathrm{H}$, Ishikawa J, Hanamoto A, Takahashi C, Shinose M, Takahashi Y, Horikawa H, Nakazawa H, Osonoe T, Kikuchi H, Shiba T, Sakaki Y, Hattori M (2001) Genome sequence of an industrial microorganism Streptomyces avermitilis: deducing the ability of producing secondary metabolites. Proceedings of the National Academy of Sciences of the United States of America $98: 12215-12220$.

Paranthaman S, Dharmalingam K (2003) Intergeneric conjugation in Streptomyces peucetius and Streptomyces sp. strain C5: chromosomal integration and expression of recombinant plasmids carrying the chiC gene. Applied and Environment Microbiology $69: 84-91$.

Rabbind Singh A, Senthamaraikannan P, Thangavel C, Danda R, Pandian SK, and Dharmalingam K (2014) ChiS histidine kinase negatively regulates the production of chitinase ChiC in Streptomyces peucetius. Microbiological Research 169:155-162.

Renkema GH, Boot RG, Strijland A, Donker-Koopman WE, van den Berg M, Muijsers AO, Aerts JM (1997) Synthesis, sorting, and processing into distinct isoforms of human macrophage chitotriosidase. European Journal of Biochemistry 244 :279-285.

Rodríguez H, Rico S, Díaz M, Santamaría RI (2013) Twocomponent systems in Streptomyces: key regulators of antibiotic complex pathways. Microbial Cell Factories 12: 1-10.

Saini DK, Pant N, Das TK, Tyagi JS (2002) Cloning, overexpression, purification, and matrix-assisted refolding of DevS (Rv 3132c) histidine protein kinase of Mycobacterium tuberculosis. Protein Expression and Purification 25 :203-208.

Saito A, Fujii T, Miyashita K (2003) Distribution and evolution of chitinase genes in Streptomyces species: involvement of geneduplication and domain-deletion. Antonie Van Leeuwenhoek 84 :7-15.

Saito A, Ishizaka M, Francisco PB, Jr., Fujii T, Miyashita K (2000) Transcriptional co-regulation of five chitinase genes scattered on the Streptomyces coelicolor A3(2) chromosome. Microbiology 146 :2937-2946.

Saito A, Miyashita K, Biukovic G, Schrempf H (2001) Characteristics of a Streptomyces coelicolor A3(2) extracellular protein targeting chitin and chitosan. Applied and Environmental Microbiology 67: 1268-1273. 
Sheeler NL, MacMillan SV, Nodwell JR (2005) Biochemical activities of the absA two-component system of Streptomyces coelicolor. Journal of Bacteriology 187: 687-696.

Singh SM, Panda AK (2005) Solubilization and refolding of bacterial inclusion body proteins. Journal of Bioscience and Bioengineering 99 :303-310.

Suzuki K, Sugawara N, Suzuki M, Uchiyama T, Katouno F, Nikaidou N, Watanabe T (2002) Chitinases A, B, and C1 of Serratia marcescens 2170 produced by recombinant Escherichia coli: enzymatic properties and synergism on chitin degradation. Bioscience Biotechnology and Biochemistry 66 :1075-1083.

Tsumoto K, Umetsu M, Kumagai I, Ejima D, Philo JS, Arakawa $\mathrm{T}$ (2004) Role of arginine in protein refolding, solubilization, and purification. Biotechnology Progress 20 :1301-1308.
Vetrivel KS, Dharmalingam K (2001) Isolation and characterization of stable mutants of Streptomyces peucetius defective in daunorubicin biosynthesis. Journal of Genetics $80: 31-38$.

Vetrivel KS, Pandian SK, Chaudhary U, Dharmalingam K (2001) Purification, cloning, and DNA sequence analysis of a chitinase from an overproducing mutant of Streptomyces peucetius defective in daunorubicin biosynthesis. Canadian Journal of Microbiology 47:179-187.

Watanabe T, Oyanagi W, Suzuki K, Tanaka H (1990) Chitinase system of Bacillus circulans WL-12 and importance of chitinase A1 in chitin degradation. Journal of Bacteriology 172:4017-4022.

Zothanpuia, Passari AK, Chandra P, Leo VV, Mishra VK, Kumar B, Singh BP (2017) Production of Potent Antimicrobial Compounds from Streptomyces cyaneofuscatus Associated with Fresh Water Sediment. Frontiers in Microbiology 8:1-13. 